$10-2016$

\title{
Hutus Aiding Tutsis during the Rwandan Genocide: Motives, Meanings and Morals
}

\author{
Daniel Rothbart \\ School for Conflict Analysis and Resolution, George Mason University \\ Jessica Cooley \\ George Mason University
}

Follow this and additional works at: https://digitalcommons.usf.edu/gsp

\section{Recommended Citation}

Rothbart, Daniel and Cooley, Jessica (2016) "Hutus Aiding Tutsis during the Rwandan Genocide: Motives, Meanings and Morals," Genocide Studies and Prevention: An International Journal: Vol. 10: Iss. 2: 76-97. DOI:

http://dx.doi.org/10.5038/1911-9933.10.2.1398

Available at: https://digitalcommons.usf.edu/gsp/vol10/iss2/8

This Articles is brought to you for free and open access by the Open Access Journals at Digital Commons @ University of South Florida. It has been accepted for inclusion in Genocide Studies and Prevention: An International Journal by an authorized editor of Digital Commons @ University of South Florida. For more information, please contact digitalcommons@usf.edu. 
Hutus Aiding Tutsis during the Rwandan Genocide: Motives, Meanings, and Morals

\author{
Daniel Rothbart \\ School for Conflict Analysis and Resolution, George Mason University \\ Fairfax, Virginia, USA \\ Jessica Cooley \\ Affiliate, Program on Ethics and Conflict \\ School for Conflict Analysis and Resolution, George Mason University. \\ Fairfax, Virginia, USA
}

\begin{abstract}
During the Rwandan genocide of 1994, Hutu extremists who launched a propaganda campaign to demonize Rwandan Tutsis, accusing them of planning to exterminate Hutus. Embracing the propaganda, gangs of Hutus went on a killing rampage, rooming the streets and ravaging Tutsis who fell prey to their assaults. Yet, the framing of Hutus as perpetrators cannot capture the work of those Hutus who actively offered assistance to Tutsis. These Hutus provided safe haven, essential material goods and emotional support to an unknown number of Tutsis. Why did these Hutus risk their lives to save Tutsis? In addressing this question, we provide the results of a study in which a small number of Hutu explained their actions. In a clear case of altruism, their efforts arose from their moral obligation to others, an obligation that centers on their good heart. A good heart is a physical embodiment of their wisdom to discover the righteous path, compassion for the suffering of others, and courage to overcome the fear in of their own suffering in carrying out the commands of their faith.
\end{abstract}

Keywords: genocide, Rwanda, Hutus, Tutsis, assistance

\title{
Introduction $^{1}$
}

In 1994 a wave of mass killings swept through the small country of Rwanda-Hutu extremists orchestrating a campaign of extermination against Tutsis. Under the control of these extremists, government forces joined two large militias groups - the Interahamwe and the Impuzamugambiin torrents of genocidal violence. A watershed moment that sparked the outbreak of the genocide was the death of the Hutu president, Juvénal Habyarimana, when his plane was shot down on April 6, 1994. The Hutu government accused the Tutsi-led Rwandan Patriotic Front (RPF) of orchestrating the president's assassination, accusing the RPF of state treason. As the anti-Tutsi rhetoric escalated, collective fears of Tutsi conquest spread like wildfire.

The violence that followed was not merely a spontaneous eruption of rage. Meticulous plans for Tutsi extermination were fine-tuned by strategists. The state-run military made lists of important Tutsis to be killed first, followed by their families and neighbors. ${ }^{2}$ The militants, who were predominantly young men, set up roadblocks and scoured communities where Tutsis could be hiding. Most attacks occurred in public places-schools, churches, marketplaces, roads and open fields. Militia groups also attacked Tutsis in their homes. Many Hutus were slaughtered in the process because they were perceived to have physical characteristics that are commonly associated with Tutsis, such as high cheekbones, or because of their economic status, such as owning cattle. The number of people who directly participated in the slaughter ranged from 175,000 to 210,000. ${ }^{3}$

The genocide ended only after the Rwandan Patriotic Front defeated the genocidal Hutu forces. By the end of the genocide, 800,000 Rwandans were murdered-one sixth of the country's population. At least 500,000 were Tutsis. ${ }^{4}$ Yet, memorials in Rwanda to the genocidal violence have prompted considerable controversy, as Elisabeth King has shown. ${ }^{5}$

\footnotetext{
${ }^{1}$ We wish to thank the anonymous readers for providing valuable observations and recommendations for changes to earlier drafts of this paper.

2 Jean Hatzfeld, Machete Season: The Killers in Rwanda Speak (New York: Farrar, Straus and Giroux, 2003), 179.

${ }^{3}$ Scott Straus, "How Many Perpetrators were there in the Rwandan Genocide?" Journal of Genocide Research 6, no. 1 (2004), 94.

${ }^{4}$ Alison Des Forges, Leave None to Tell the Story (New York: Human Rights Watch, 1999), 105.

${ }^{5}$ Elisabeth King, "Memory Controversies in Post-Genocide Rwanda: Implications for Peacebuilding," Genocide Studies and Prevention 5, no. 3 (December 2010), 293-309.
} 
But an unknown number of Hutu civilians resisted demands by the state military and local militias to deliver Tutsis over for the slaughter. These Hutus secretly offered Tutsis safe haven, material assistance, and emotional comfort. In some cases sympathetic Hutus directly confronted the militia groups, imploring them to stop killing Tutsis. While some would-be rescuers did succeed in saving Tutsis, an unknown number of them failed-and were themselves murdered in the process.

And herein lies the question: Why did some Hutus find the anti-Tutsi propaganda spurious, while a majority of Hutus accepted the messages of hatred and fear as truth? Why did some Hutus put their own lives on the line to save Tutsis? Addressing these questions, we examined the motives and conscious reasons for a select group of Hutus who sought to rescue Tutsis. For this research we drew upon the testimony of thirty-three self-identifying rescuers who were interviewed in Rwanda between July and August of 2010. At the time of this research approximately forty Rwandans were officially recognized as rescuers, with time and resources allowing for thirty-three interviews to be obtained for this study. The interviewees were selected by two Rwandan NGOs-Memos and IBUKA. Beginning in 2007, these two NGOs were responsible for identifying and officially recognizing Rwandan rescuers through a three-step process in order to assure the integrity of the rescuer title and prevent any fraudulent claims. First, the staff members would gather testimony of those survivors who claimed that they were rescued by a Hutu during the genocide. Second, an official from one of the NGOs would engage in an in-depth investigation of the claims for their accuracy. The investigator interviewed the potential rescuer without identifying their intention to identify rescuers, but just asking more general questions about the potential rescuer's experience during the genocide. If the potential rescuer claims to have helped Tutsis during the genocide, the investigator would then interview any witnesses (i.e. neighbors, family members) to corroborate the rescuer testimony. The investigation process was designed to ensure that potential rescuers were not motivated by the lure of personal gain, and were simply acting in accord with a genuine intention to help. Third, staff members of the investigating NGO would render a judgment about the authenticity of the rescue itself. Currently, this is the only method of rescuer validation. For the purpose of this paper we rely on this methodology for officially recognizing rescuers, which depends heavily on the narrative and interpretative accounts of the rescuers' memory of such events. Moreover, we do not claim to extend our findings to all rescuers.

Regarding the identification of rescuers in Rwanda, Lee Ann Fujii argues that the strict duality between perpetrators of genocidal violence and rescuers is quite misleading, since some people who acted to persecute Tutsis sometimes also acted to offer them aid. ${ }^{6}$ However, in Rwanda the official title of rescuer was granted by these two NGOs only to those for whom there was no evidence of any act of persecuting or harming Tutsis. Individuals who both participated in violence against certain Tutsis but then helped others were not declared to be rescuers.

Among the thirty-three interviewees, twenty-six were male and seven were female. Twentynine self-identified as Christians-Protestants, Catholics or Seventh-Day Adventists-one was Muslim, and three held the traditional beliefs of ancient Rwandans before Christianity came to the country. Five identified as poor, twenty as being well off and eight as rich. The SES classification used by the Rwandan rescuers interviewed differs from western SES categories. According to these rescuers, "well off" was quantified as owning land and cows and being able to afford school fees, with "rich" referring to having a lot of cows, land, and possibly cars. Regarding educational status, three held a university degree, three attended vocational or secondary school, seventeen attended or completed primary school, nine had no formal education and one was unknown.

Most of the interviews took place in a Kagali hotel or in the rescuers' homes, which were often in close proximity to the rescue efforts. All the interviews were conducted in the local language, Kinyarwandan, with subsequent translation to English. Each interview took two to three hours, with audio and video recordings for all but two of them. A semi-structured interview format was utilized, which included questions meant to obtain demographic information about the rescuers'

\footnotetext{
${ }^{6}$ Lee Ann Fujii, "Rescuers and Killer-Rescuers during the Rwanda Genocide: Rethinking Standard Categories of Analysis," in Resisting Genocide: The Multiple Forms of Rescue, ed. Jacques Semelin et al. (New York: Columbia University Press, 2011), 145-157.
} 
lives before the genocide, their experiences and actions during the genocide, their reasons for rescuing and what rescuing meant to them, as well as how their lives had been impacted since the genocide. (See Appendix for interview questions.) All these questions were posed to each interviewee in the order given below in the Appendix. Thematic analysis was deployed to all of the testimony for this research. The key points of the testimony were coded using the speaker's language, followed by the construction of categories that captured the interviewees' primary themes.

We believe that the investigation of rescuers during the Rwandan genocide is under-examined by academic studies of the Rwandan genocide, most of which focus primarily on the Tutsis' suffering and Hutu killers' motives, means, and mindset. Elisabeth King provides an excellent analysis of the memorials in Rwanda to the genocidal violence and the politics of creating public spaces for the victims. Two studies of rescuers acting during the Rwandan genocide are from Charles Kabwete Mulinda and Fujii. ${ }^{7}$ In 2004, the Kigali Genocide Memorial opened, using exhibits and documentation as a form of education and genocide prevention. Initially focusing mostly on survivors' experiences, the memorial currently houses twenty-eight rescuer testimonies on their website.

We provide a broader historical context for rescuing under conditions of genocidal violence with a summary in section 1 of the rescuers of Jews during the Holocaust. Then in section 2 we examine the Hutus' rescue efforts in Rwanda, defining such efforts in three distinct stages. In section 3 we present our findings about the motivations of the Hutu rescuers, with special emphasis on the role models that influenced their sense of self in relation to others. These motivations are then examined in section 4, specifically in relation to how the lessons the rescuers learned from their role models motivated their efforts to save Tutsis. We found that each Hutu interviewed purported to act out of compassion by offering Tutsis safe haven while knowingly placing themselves in mortal danger. We conclude in section 5 with summary observations about the rescuers' sense of moral conviction drawn from the lessons they learned from their experiences during the genocidal violence.

We recognize that the term "rescuer" implies a savior, one who frees someone from confinement, or delivers from bondage. In recent years, some analysts have raised questions about the merits of using this term as a primary category of study. They argue that the term "rescuer" does not adequately capture the fact that, during the Holocaust, some Germans sought to offer assistance, comfort or support to Jews escaping the Nazi terror without actually saving them outright. A wide range of activities have been documented about individual acts of assistance to Jews. The term "helpers" is now widely used in place of "rescuers" to represent those people who sought to offer aid of any form to those targeted by perpetrators of genocidal violence. ${ }^{8}$ While finding merit in this use of "helpers," we recognize that the interviewees gathered for this research on the Rwandan genocide were identified as rescuers by the NGOs with whom we worked. We defer to their usage of this term.

\section{Rescuers of the Holocaust}

To provide historical context to the rescuer efforts in Rwanda, we turn to the similar efforts of civilians living under Nazi occupation during World War II. The number of active rescuers during the Nazi occupation of Europe is low, comprising only one half of one percent of the total civilian population. ${ }^{9}$

In the earlier writings on rescuers of World War II, many researchers advanced the notion that rescuers of Jews during the Holocaust represent a clear case of altruism, with the understanding

\footnotetext{
${ }^{7}$ Charles Kabwete Mulinda, "Crossing a Border to Escape: Examples from the Gishamvu and Kigembe Communities of Rwanda," in Resisting Genocide: The Multiple Forms of Rescue, ed. Jacque Semelin, et al. (New York: Columbia University Press, 2011), 345-361; Fujii, "Rescuers and Killer," 145-157.

${ }^{8}$ Christian Gudehus, "Helping the Persecuted. Heuristics and Perspectives (exemplified by the Holocaust)," Online Encyclopedia of Mass Violence (2016), accessed August 17, 2016, http://www.sciencespo.fr/mass-violence-war-massacreresistance/en/document/helping-persecuted-heuristics-and-perspectives-exemplified-holocaust.

${ }^{9}$ Pearl M. Oliner and Samuel P. Oliner, The Altruistic Personality: Rescuers of Jews in Nazi Europe (New York: Free Press, 1988), 8.
} 
that altruism is exhibited by some people for certain reasons under certain situations. What exactly is the meaning of altruism when referring to people who offer assistance to persecuted group members in the context of genocidal violence? Many researchers addressing this question endorse the presence of an altruistic personality, which is characterized by behavior that is perceived to be more kind, compassionate and helpful in comparison to others. ${ }^{10}$ Even the advocates for the presence of an altruistic personality - or some form of pro-social personality - recognize the critical importance of situational factors, that the character and kind of altruistic personality exhibit rests on situational factors. ${ }^{11}$

One definition of altruism given by Oliner and Oliner rests on four defining factors. ${ }^{12}$ First, the rescuers intentionally aided Jews who were clearly in peril, offering them safe haven, material assistance, or psychological comfort. Second, the rescuers acted of their own free will-they were not compelled, commanded, or coerced to take such actions by outside forces, such as a militant group of partisans. According to one study, ninety-nine percent of the Holocaust rescuers were aware at the time of their efforts of the Nazi campaign to exterminate the Jews. Interestingly, this awareness of the Nazis' regime was not limited to the Holocaust rescuers. Most non-rescuing civilians also knew about the extermination campaign during the war. But unlike the rescuers, these civilians acted from the standpoint of self-survival, fearing more the consequences they might face for helping the Jews, if discovered by German military forces - as if declaring, "They should take care of themselves; we have our own problems."13 Third, rescuers recognized the mortal dangers that such deeds posed; they understood that, if caught, the authorities would execute them and their loved ones. Fourth, rescuers did not expect material or tangible reward for their efforts from anyone, including those seeking safe haven. Explanations for the rescuer's deeds-why they risked their lives to save Jews during the war-have been elusive. These rescuers do not fit easily into a single sociopolitical category. In one study, many rescuers drew upon their moral conscience as a powerful psychic drive. For example, some rescues were driven by their ethical beliefs that made it imperative to help those in need. Other rescuers grounded their actions in socialist or communist doctrine, which called for resistance against the Nazi invaders. ${ }^{14}$ Still others were driven by a strong emotional attachment to individual Jews for whom the rescuers had special feelings or love, or to the Jewish people as a whole. The famous case of Oscar Schindler to save Jews illustrates how many Polish rescuers had some special affinity toward Jews. ${ }^{15}$

But these rescuers did not limit their efforts merely to friends. In fact, approximately half of the people that the rescuers sought to save were total strangers to them. The relationship between rescuers and those rescued as reported by Jewish survivors is as follows: Strangers, $51 \%$; Acquaintances, 21\%; Friends, 19\%; and Work with commercial ties, 9\% (out of total number of 412). ${ }^{16}$

In one study, the explanation for their rescue efforts is moralistic, with most rescuers coming from families with strongly held humanitarian values. When asked about their motivation, most rescuers (87\%) invoked their deep ethical commitment to care for those in danger, grounded in a

\footnotetext{
${ }^{10}$ Hans W. Bierhoff, Renate Klein, and Peter Kamp, "Evidence for the Altruistic Personality from Data on Accident Research," Journal of Personality 59, (1991), 263-280; William A. Galston, “Cosmopolitan Altruism," Social Philosophy and Social Policy 10, (1993), 118-134; Dennis L. Krebs and Frank Van Hesteren, "The Development of Altruistic Personality," in Embracing the Other: Philosophical, Psychological, and Historical Perspectives on Altruism, ed. Pearl M. Oliner, et al. (New York: New York University Press, 1992), 1142-69; Oliner and Oliner, "Promoting Extensive Altruistic Bonds: A Conceptual Elaboration and Some Pragmatic Implications," in Embracing the Other, 369-389; Van Hesteren, "The Self in Moral Agency: Toward a Theoretical Model of the Ideal Altruistic Personality," in Embracing the Other, 170-193.

${ }^{11}$ Frederico Varese and Meir Yaish, "Resolute Heroes: The Rescue of Jews During the Nazi Occupation of Europe," European Journal of Sociology 46 (2005), 153-168.

${ }^{12}$ Oliner and Oliner, The Altruistic Personality, 173, 249, 299.

${ }^{13}$ Ibid., 289.

${ }^{14}$ Eva Fogelman, Conscience and Courage: Rescuers of Jews During the Holocaust (New York: Doubleday, 1994), 162-164.

${ }^{15}$ Ibid., 182-185.

${ }^{16}$ Nechama Tec, When Light Pierced the Darkness: Christian Rescue of the Jews in Nazi-occupied Poland (New York: Oxford University Press, 1986), 227.
} 
strong belief in universal humanism, in particular, the belief in the inherent worth of each person. ${ }^{17}$ For a majority of these rescuers, this belief was not driven by their religious convictions, and the rescuers' religious affiliations were not significantly different from those of non-rescuers-the range of participation in religious traditions was approximately identical for both groups. ${ }^{18}$ Yet the moral imperative to care for those in peril motivated them in their efforts to save Jews, particularly after witnessing Nazi brutality against Jews in their community. ${ }^{19}$

During their efforts to save Jews, the moral bonds between rescuers and Jews intensified through the shared experience of the rescue acts themselves. ${ }^{20}$ Each episode of saving Jews brought personal satisfaction, a deep sense of pleasure in knowing that their deeds had such a profound moral impact. ${ }^{21}$ This self-satisfaction should not be confused with selfishness. The rescuers also experienced significant psychological distress from the intense fears that accompanied their courageous but dangerous actions. In Poland, for example, the hatred of Germans at that time contributed directly to rescuers' empathy for the Jews, in part because Polish non-Jews experienced mass executions on a scale comparable to that of Polish Jews. Stunned by the Nazi brutality against the Jews, the Polish rescuers were driven by three primary motivations: political convictions, religious teaching, or moralistic lessons from family members such as parental figures. ${ }^{22}$ For example, a minority of Polish rescuers found inspiration in the humanist themes of Christianity. Some of these rescuers were priests motivated by the Christian values to show compassion, charity and generosity to those in need. ${ }^{23}$ In like manner, some Catholic bishops in France, Belgium, Holland and Italy openly denounced Nazi policies against the Jews. ${ }^{24}$ But religious conviction does not always correlate to efforts to save Jews. ${ }^{25}$ Many other priests, and parishioners with strong religious convictions, retained strong anti-Semitic sentiments stemming from a long tradition of bigotry against Jews by the Catholic Church in Poland. Some priests in Poland implored their congregants to denounce the Jews and report their presence to local officials; such priests declared that good Catholics should obey local authorities about political matters such as the treatment of Jews ${ }^{26}$ In a later article Tec qualifies significantly her earlier claims about the altruistic action of rescuers, acknowledging those cases where the rescuing behavior of Gentiles was motivated by a desire for profit from the persecuted Jews. ${ }^{27}$

Many of the early studies cited above of rescuers of Jews offer empirically rich examination of the rescuers' motives for saving Jews, their character traits and their assumptions before and during the Holocaust about Jews. Most of the primary source data gathered for these studies came from interviews and questionnaires of the rescuers years after the war ended. But some analysts have questioned the veracity of such data since it rests on memory and memory can be fallible for a variety of reasons. Many psychologists have shown that memory is not a passive receptacle of pure "content" that presumably represents a true picture of the past and that memory of the past is never "carried down in pure form." Memory is always subject to reinterpretation. ${ }^{28}$ Memory alters during one's life, impacted by one's emotions, moralistic commitments regarding notions of right or wrong, and one's self-image in relation to others. ${ }^{29}$ Recognizing such fallibility, for purposes

\footnotetext{
${ }^{17}$ Oliner and Oliner, The Altruistic Personality, 163-164.

${ }^{18}$ Ibid., 156, 289.

${ }^{19}$ Peter Suedfeld and Stefanie de Best, "Value Hierarchies of Holocaust Rescuers and Resistance Fighters," Genocide Studies and Prevention 3, no. 1 (2008), 38-40.

${ }^{20}$ Ibid., 38-39.

${ }^{21}$ Oliner and Oliner, The Altruistic Personality, 249.

${ }^{22}$ Tec, When Light Pierced the Darkness, 189.

${ }^{23}$ Ibid., 137.

${ }^{24}$ Fogelman, Conscience and Courage, 172.

${ }^{25}$ Tec, When Light Pierced the Darkness, 187.

${ }^{26}$ Ibid., 137.

${ }^{27}$ Tec, "Who Dared to Rescue Jews, and Why?" in Resisting Genocide: The Multiple Forms of Rescue, ed. Jacques Semelin et al. (New York: Columbia University Press, 2011), 101-122.

${ }^{28}$ Jeffrey Blustein, The Moral Demands of Memory (New York: Cambridge University Press, 2008), 67-68.

${ }^{29}$ Suzanne Beer, "Aid Offered Jews in Nazi Germany: Research Approaches, Methods, and Problems," Online Encyclopedia
} 
of this study we adopt a narrative perspective on memory, according to which narratives of the past have their own history, and they are subject to reshaping, fine-tuning, revising, and ignoring elements of one's memory over time. In memory we take on multiple roles of a drama, becoming the drama's author, primary character and outside critic.

More recent studies of rescuing behavior in the context of the Holocaust have produced an extensive body of findings from a variety of research perspectives. Each perspective offers an analytical lens that rests on a model for understanding the breadth and depth of such behavior and related social processes. Of course, for each perspective the salience given to certain kinds of categories and processes has its limitations, blocking access to other sorts of categories and processes. We mention briefly four examples of such perspectives, with the understanding that a detailed summary of all of these perspectives surpasses the scope of this article.

1. One perspective privileges situational factors as motivating certain people to offer aid to those persecuted. For example, in one study German Gentiles were confronted by persecuted Jews who were pleading for their assistance, offering Gentiles a situation in which the opportunity for helping them arose. In others cases the pleas to would-be helpers did not come from the Jews directly but were conveyed by third party surrogates who sought assistance on behalf of the Jews. ${ }^{30}$ To be sure, the expressed motivation to offer assistance did not always conform to the "helpers" action. Abusive behavior by Gentiles was not uncommon, such as demands for payment or for sexual favors from Jews.

2. In another perspective researchers give primacy to character traits of so-called "doers" that are evidence in their tendency to take responsibility for the course of events, to make independent interpretations of the situation before them and to render judgments that may deviate from those of others. ${ }^{31}$

3. The network perspective focuses on the influence of social groups that offer aid and/or support to those persecuted, reflecting networks of social relations. During World War II, some networks of relations were created before the genocidal violence erupted while other networks were formed during the violence. In one study a socialist group that flourished in Germany before the war-the Bund-offers sanctuary to Jews in Nazi Europe. In another study of a Holocaust survivor, the researcher categorizes the kind of help received as food, accommodations, money, and assistance in brokering connections with others. ${ }^{32}$

4. Some researchers adopt an historical-societal perspective in arguing that the chances of European Jews surviving Nazi occupation depended upon certain historical and social conditions. For example, one study shows that the probability of survival is correlated to a relatively high number of Catholics in the area where Jews sought help. ${ }^{33}$ Other researchers deploy a broader analytical lens by probing the social-political-historical conditions that existed during and prior to efforts to assist Jews. One researcher explains the acts of rescuing Jews during World War II by examining the social contexts in which such acts occurred, such as cohesiveness of the prewar Jewish communities, the integration of these communities to larger non-Jewish society; and the prewar history of defying, or not, the authorities. In conjunction to these contextual factors, individual motivations for rescuing Jews were identified, such as religious conviction, humanitarian commitments, friendship, rejection of Nazi policies, and financial gain. ${ }^{34}$ We should not interpret such

of Mass Violence (2014), accessed February 19. 2016, http://www.massviolence.org/Aid-Offered-Jews-in-Nazi-Germany.

${ }^{30}$ Varese and Yaish, "Resolute Heroes: The Rescue of Jews During the Nazi Occupation of Europe," 153-168; J. Elster, "Rational Choice History: A Case of Excessive Ambition," American Political Science Review 94, no. 3 (2008), 685-695.

${ }^{31}$ Bierhoff, Klein, and Kamp, “Evidence for the Altruistic Personality," 263-280.

${ }^{32}$ M. Düring, "The Dynamics of Helping Behaviour for Jewish Refugees During the Second World War. The Importance of Brokerage," in Knoten und Kanten: soziale Netzwerkanalyse in Geschichts- und Politikwissenschaften, ed. M. Gamper et al. (Bielefeld: Transcript, 2015), 321-340.

${ }^{33}$ Marnix Croes, "The Holocaust in the Netherlands and the Rate of Jewish Survival," Holocaust and Genocide Studies 20, no. 3 (2006), 482-484.

${ }^{34}$ Bob Moore, Survivors: Jewish Self-Help and Rescue in Nazi-Occupied Western Europe (Oxford and New York City: Oxford University Press, 2010), 8-12. 
perspectives as mutually exclusive; elements from multiple perspectives can be combined to account for the evidence on a case-by-case basis. We agree with those analysts who argue that a comprehensive study of helping requires attention to multiple perspectives that draw attention to some combination of behavior, motivations, situational factors, social networks and character traits..$^{35}$

In our study of rescuers of Rwanda, we find relevance to factors from the above four perspectives, that is, to the situation of being confronted by persecuted Tutsis, the self-sense of taking responsibility for aiding Tutsis in clear defiance of the Hutu extremists orchestrating the propaganda campaign against Tutsis, a network of social relations to influential figures in their lives, and, to a lesser degree, the historical-social context.

\section{Rescuing in Rwanda: As a Complex Interaction}

Based on narrative analysis of the interviewees' testimony, we focus on the rescuers' interactions with Tutsis seeking sanctuary and their confrontation with the killers themselves. Probing their stated reasons for offering aid to Tutsis, we explore their beliefs before the genocide, their perceptions of the killers, and their apparent motives, rationale, and reasons for taking such risks. We give special attention to role of influential figures in their lives, those individuals who presumably gave them a moral education, instilling in them normative notions about what is morally right and wrong in relations with others. We begin with an account of the act-or, more accurately, acts-comprised by the rescue.

The process of rescuing Tutsis in Rwanda was neither momentary nor limited to a single action. Many rescue efforts began incrementally, hiding a few individuals for a short period of time. As word of the rescue efforts spread throughout the community, more Tutsis would appear at the rescuers' homes, pleading for a safe haven. Before long, the act of sheltering a small number of Tutsis burgeoned to many, and their length of stay increased from a few days to many weeks. As the murderous gangs began to catch wind of the growing rescuing efforts, some rescuers took precautionary action by transporting Tutsis to Burundi or Zaire, using forged IDs or pretending that the rescuers were the parents of transported children.

Based on a distillation of testimony of interviewees, their rescue efforts involve three distinct stages: (1) witnessing the brutal treatment that Tutsis faced, either through direct observation or word-of-mouth, (2) finding and offering assistance to at least one Tutsi who faced mortal danger, and (3) interacting directly with the killers who were searching for Tutsis.

(1)

In the prelude to the 1994 genocide, Hutu extremists launched an intense media campaign prior to the genocidal violence, spreading tales of Tutsi plans to conquer Rwanda and brutalize Hutus. After Hutu extremists established the Radio Télévision Libre des Mille Collines (RTLM) in 1993, they dominated the airwaves with horrific tales of Tutsis committing atrocities against the oppressed Hutus. Stoking the flames of aggression, the broadcasters reiterated the accusation that the Tutsi people planned to conquer the nation by infiltrating major institutions and claimed that Tutsis disguised their real intention of ultimate domination by lulling innocent Hutus into complacency. ${ }^{36}$ Broadcasters implored listeners to vent their anger by calling into the radio station and sharing their stories of power-hungry and domineering Tutsis. With such broadcasts, Tutsi evil deeds became a topic of social fascination, bordering on obsession, for the callers.

In like fashion, the newspaper Kangura ran story after story about Tutsi defects and offenseswickedness, obsession with power, and insatiable thirst for domination. One article recounted the alleged nefarious practice of Tutsi women seducing innocent and unsuspecting Hutu men, thereby producing hybrid descendants, within a larger political plot of total Rwandan conquest. ${ }^{37}$ Other storytellers invoked the genocide of World War II, portraying Hutus as the "Jews of Rwanda,"

\footnotetext{
${ }^{35}$ Gudehus, "Helping the Persecuted. Heuristics and Perspectives (exemplified by the Holocaust)."

${ }^{36}$ Daniel Rothbart and Tom Bartlett, "Rwandan Radio and Hutu/Tutsi Positioning," in Global Conflict Resolution through Positioning Theory, ed. Fathali M. Moghaddam et al. (New York: Springer, 2008), 227-229.

${ }^{37}$ Josias Semujanga, Origins of Rwandan Genocide (Amherst: Humanity Books, 2003), 196-97.
} 
on the brink of their own holocaust at the hands of the "Nazi" Tutsis. In stunning irony to this metaphor, the propagandists also depicted Tutsis as insects or snakes who slither through the dark, spreading their venom to innocent Rwandans - a chilling reminder of the insect images that Nazi propagandists used to dehumanize Jews. In one story published in Kangura, March 17-18, 1993, Tutsis were demonized as Inyenzi, or cockroaches:

We are not mistaken in saying that a cockroach gives birth to another cockroach. All these attacks have as their objective to restore the monarchy and feudalism. The unimaginable crimes that the Inyenzi of today commit against the citizens remind one of those made by their ancestors: killing, plundering, raping girls, and women, and so on. If in our language someone calls something a snake, that by itself is enough. ${ }^{38}$

Such propaganda, withits vile characterizations of Tutsis, constitutes a form of psychological violence. It had its intended effect on many Hutus, but not all. The Interahamwe and Impuzamugambi, who comprise the murderous gangs carrying out the genocidal violence, fully accepted the disseminated "truths" about Tutsi evils. For example, one such perpetrator of violence, in recounting his earlier belief that Tutsis were inherently subhuman, admitted, "We called them "cockroaches," an insect that chews up clothing and nests in it, so you have to squash them hard to get rid of them. We didn't want any more Tutsis on the land." ${ }^{39}$ Another perpetrator, who served twelve years in prison for crimes committed during the genocide, recounts, "We no longer saw a human being when we turned up a Tutsi in the swamps." ${ }^{\prime 4}$ Another perpetrator serving his twelve-year sentence in prison for murdering Tutsis recounts the days before and after the president's death:

The radios were yammering at us since 1992 to kill all the Tutsis; there as anger after the president's death and a fear of falling under the rule of the inkotanyi... The Hutu always suspects that some plans are cooking deep in the Tutsi character... He sees a threat lurking in even the feeblest or kindest Tutsi. But this is suspicion, not hatred. The hatred came over us suddenly after our president's plan crashed. The intimidators shouted, "Just look at these cockroaches - we told you so!" And we yelled, "Right, let's go hunting!"41

The outset of the violence in April of 1994 was terrifying; the rescuers experienced intense fear at the sight of dead bodies in the streets, the sudden appearance of the Interahamwe prowling about, and the murmured stories of mass executions. A sense of dread washed over them, along with the feeling of impotence in the face of the overwhelming violence. Most of the interviewees claimed to have ignored the propaganda. One interviewee reported to have listened to the songs of the Hutu radio stations, but was disturbed by the hate-filled lyrics of music being blared in the streets: "I saw that there was a war behind these songs that would kill people." ${ }^{42}$

Rejecting the propaganda orchestrated by Hutu extremists, all the rescuers interviewed for this study resisted-and in some cases, actively obstructed-the killers' extermination efforts. Their decision to protect Tutsis arose from the jarring experiences of witnessing or hearing about the violence in their midst. Prior to their rescue efforts, most interviewees directly observed government soldiers or Interahamwe killing local residents. One interviewee reported to have seen neighbors being killed, following by looting material items in the neighbors' home. ${ }^{43}$ Another rescuer witnessed harassment of a Tutsi family living next door. ${ }^{44}$ Another rescuer reported that her father was killed because of his efforts to save Tutsis. He was targeted because his neighbors

\footnotetext{
${ }^{38}$ Chrétien, Jean-Paul and Reporters sans Frontières. Rwanda: Les médias du génocide (Paris: Éditions Karthala, 1995), 275-276.

${ }^{39}$ Hatzfeld, Machete Season, 231.

${ }^{40}$ Ibid., 231.

${ }^{41}$ Ibid., 219.

${ }^{42}$ Participant \#3. Identifying information such as names, professions, dates, and areas of residence is being withheld to protect the anonymity of the interviewees. Interviews are cited, herewith, according to the participant number.

${ }^{43}$ Participant \#1.

${ }^{44}$ Participant \#3.
} 
denounced him for listening to the pro-RPF radio broadcasts, which were cast as the "radio of the enemy." 45

(2)

For most interviewees, their rescuing efforts began with the desperate pleas of a few Tutsis. In one case a close friend came to the interviewee's home, lamenting that "this is our last day and then you will escort us" referring to her burial. ${ }^{46}$ The rescuer invited her to her home and offered anything that she wanted. Many of the interviewed took it upon themselves to save children. In another case an interviewee witnessed people being killed while walking on the road. This rescuer picked up a young girl, who cried, "Please don't kill me!" Comforting the girl, the rescuer, brought her to the rescuer's home. ${ }^{47}$ Another interviewee reported how her husband sought to rescue three children, but he was discovered and killed. ${ }^{48}$ One rescuer took care of Tutsi children whose parents were killed..$^{49}$ Another rescuer hid children - her own and others - in her home. When she heard a knock on the door, fearing the worst, this rescuer recounted how she told the children, "It is now our time to die; let's be killed together." ${ }^{50}$ But the knock came from a man seeking refuge for himself and his family, all of whom were strangers to this rescuer. ${ }^{51}$

Some rescuers knew those whom they sought to save before the genocide. For example, a rescuer, who was known as a midwife, was approached by her patients. Bringing some to the hospital and others to her church, she claims to have saved thirty people. ${ }^{52}$ Other rescuers sought to protect both acquaintances and strangers. Five Tutsis stayed in one rescuer's home and others (no numbers were specified) hid in the bush behind the home. ${ }^{53}$ Another rescuer, who was a pastor, was approached by many people-some members of his church and others strangers to him, seeking refuge. The pastor did not know each person prior to the genocide, but he was known for his kindness by local residents. One would-be victim pleaded, "Pastor, please hide me. They have killed my parents." ${ }^{54}$ This pastor took in hundreds more, moving them from his home to his church. When killers demanded entry, he declared, "You cannot enter this church. You must kill me first before you kill them." The killers left the church, vowing to return. The pastor then scattered the Tutsis in various locations. When the killers returned, the church was empty. The pastor claims to have saved 320 people. ${ }^{55}$

Most of the interviewees recalled how they began hiding people in their own homes. Tutsis often used simple measures to avoid detection, such as hiding in the rescuers' bedrooms, behind furniture, or in attics. In cases where the rescuers' homes became overcrowded, the Tutsis were sent to the bush to hide. Fearing detection, the rescuers sought alternative locations, often based on momentary decisions. Some rescuers moved people from one hiding place to another as they witnessed more killing in their neighborhoods and feared detection by the murderous gangs. In another case, a rescuer produced a new ID card for a Tutsi woman, identifying her as a Hutu. This woman was saved as a result, escaping to Butare. ${ }^{56}$

One rescuer reported, "We were worried that we would now be targeted, since this man [a Tutsi] was taking refuge in our home. People started being killed around the neighborhood. Fidel

\footnotetext{
${ }^{45}$ Participant \#11.

${ }^{46}$ Participant \#1.

${ }^{47}$ Participant \#6.

${ }^{48}$ Participant \#7.

${ }^{49}$ Participant \#1.

${ }^{50}$ Participant \#5.

${ }^{51}$ Participant \#5.

${ }^{52}$ Participant \#3.

${ }^{53}$ Participant \#4.

${ }^{54}$ Participant \#2.

${ }^{55}$ Participant \#2.

${ }^{56}$ Participant \#1.
} 
was killed the next day." ${ }^{57}$ As the murderous gangs roamed the streets, this rescuer felt that the only way to avoid detection was to hide in the ground-literally:

...We were really worried and we thought that we were going to die too. Then, I decided to dig a hole where everyone can go and hide. We made a big hole so that we had another place for hiding. Whenever we would dig, we would take the soil to be dumped about 200 meters away so that it wouldn't be obvious that we just made a hole. It wasn't easy, but then we covered it with grass. We hid everyone in the hole and almost right after we hid them, we had an attack come to our house... But by the help of God they did not find anyone who was hiding. Then another attack came. The second attack really gave us real trouble. We could hear [the killers] saying, "We must not leave any stone unturned because we must leave this place with some dead Tutsis because we know that they are hiding here."... This specific attack has left me traumatized because of the way they came in, how many of them there were and how they behaved towards us. ${ }^{58}$

This rescuer claims to have saved about thirty-five people through his efforts.

(3)

Most of the interviewees recounted their terrifying encounters with the killers, which in some cases led to beatings. One interviewee described her husband's efforts to hide children. Confronting the killers in their home, he refused their demands to turn over Tutsis, saying, "No, no, no, no." He then insulted the killers' intelligence. "You Hutus, you don't look far from your nose," which means they are not thinkers. ${ }^{59}$ Another interviewee recounted how her father reprimanded the killers:

During the planning meetings, the killers were openly telling us that "today we will kill you even though you did well to us. If we find you hiding Tutsis, because you have been suspected, we will kill you too." They were telling us this without knowing that we were already hiding them... ${ }^{60}$

Another interviewee recalled how his uncle participated in the slaughter and demanded to know where the Tutsis were hiding:

The killers were my relatives. I knew them. They were family! They would come and demand the children. They even killed my cousin's wife because she was a Tutsi. And after killing her, I really begged them to give me her corpse, so that I could go and bury her. So, we went to bury my cousin's wife, and my uncle came-who was a big Interahamwe-and he asked me for the Tutsi children I was hiding... I told my sister's husband... "I will not give you those children. I cannot let you kill them. I will kill them myself first." ${ }^{\prime \prime}$

This rescuer was willing to sacrifice the lives of these children, and probably himself in the process, rather than relinquishing the children to the killers. With this daring gamble, the rescuer was tacitly accusing the killers of depravity. Through his efforts, the rescuer claims to have saved five people.

Some rescuers had the courage to bargain with the killers. Bribery was effective in some cases. One rescuer bribed the killers with food; when the food ran out, they stole all of the rescuer's possessions. Another rescuer recounted how he offered his cow to the killers in exchange for leaving the children in peace. He claims that these children survived the war. Another rescuer was prepared to sacrifice himself if that would save those whom he was hiding. "I decided that when the killers came to my place, before killing these people, they must kill me." ${ }^{62}$

${ }^{57}$ Participant \#9.

${ }^{58}$ Participant \#9.

${ }^{59}$ Participant \#7.

${ }^{60}$ Participant \#8.

${ }^{61}$ Participant \#1.

${ }^{62}$ Participant \#2. 
Two interviewees recounted how they resisted the militia groups with force of arms. In one case, the interviewee joined community members who mobilized to protect about 150 people, brandishing guns and makeshift weapons, such as sticks, spears and arrows, to ward off the attackers. He reported, "We kept fighting the different raids that came and eventually [the Interahamwe] stopped coming back. The next day the RPF came and we became a protected zone." 63

In another case a rescuer apparently witnessed the slaughter of Tutsis immediately after the president's plane was shot down. He immediately called a meeting of people in his sector, requesting that everyone assist Tutsis who were engulfed in the campaign of violence. Not aware of his effort to undermine this campaign, the Interahamwe offered him money to join them in exposing Tutsis. After refusing their request, he took up arms against the killers. Preparing for one such attack by the Interahamwe, he joined a large group of resisters - about 120 Hutus in total-in armed resistance, positioning about fifteen people with guns around his house. ${ }^{64}$ He remembered well one such skirmish with the killers:

On April 8 [the Interahamwe] wanted to come to my sector to kill the Tutsis here. I went to the Tutsi families and told them not to worry. I told them that no one would be against them, and that if they die we will all die together. I asked them to come to my home, so that I could protect them. Five families came totaling 30 people... I had many of my trusted people who had guns, and we defended against the killers. I went fifty meters above my home where I could see [the killers] coming. And when they came around 8:00 pm, I started to shoot them. And they started to curse at me saying that I will run out of bullets. I said that if I do, then all of us will die together. I shot at them again and they ran away. They started to loot, eat cows and destroying houses. But we continued to protect everyone at my house and they all survived. ${ }^{65}$

This armed counter-attack allegedly succeeded in saving many people, although he does not know the exact number.

\section{Why Rescue?}

What motivated a small number of Hutus to risk their lives to save Tutsis? After listening to the life histories of the rescuers and hearing about their experiences during the genocide, we chose to address this question by directly asking the interviewees why they rescued. Their testimony revealed consistent patterns; most interviewees repeatedly stated that their decision to rescue was directly connected to their sense of self and sense of interconnectedness with Tutsis. The interviewees unanimously expressed a clear identification with being a good person or a good Christian, which in turn meant having a good heart. As one interviewee explained, "It was my heart that made me do it. I could not let people die like that and then call myself a good Christian." ${ }^{\prime 66}$ For this rescuer, identifying herself as a good Christian made rescuing a necessary action. When asking another interviewee why she risked her life to help her neighbors, she stated:

Rescuer: I feel that my heart convinced me to do so. I saw innocent people dying and I thought that it was better to die with a friend or relative than to live and let them die. Not helping was never an option. ${ }^{67}$

Interviewer: Why do you think your heart convinced you to do this?

Rescuer: Because my heart knows that we are all the same.

\footnotetext{
${ }^{63}$ Participant \#20.

${ }^{64}$ Participant \#18.

${ }^{65}$ Participant \#18.

${ }^{66}$ Participant \#31.

${ }^{67}$ Participant \#2.
} 
For this rescuer, having a good heart implied their equal moral and social status with Tutsis. Again, this theme of equality was repeated by interviewees as a primary justification for helping. As another rescuer describes:

Even though the leadership was sensitizing people to kill, I did this because I love people. I love all humans. I can tell you that a person is not supposed to die from another human in that way. They [the killers] had changed into animals when they were killing. I saw them change and they were no longer humans. On the outside they looked human, but on the inside they were not. To be able to kill young children, while they cry out for mercy is inhuman. I couldn't be an animal like the others. As a human, I have to do the things that a human must do.

This testimony illustrates their claim that the act of killing nullifies the agent's own humanity, reducing the individual to the status of an animal. For these interviewees, their choice to help was not conceived of as an option - where they could decide to help or not-and instead was more of an irrefutable characteristic or expression of their sense of self and their relationship to Tutsis.

Such replies then led us to inquire about social underpinnings of their notions of identity and difference. We sought to understand how such notions became pivotal to their decisions to offer aid to Tutsis, decisions that deviated markedly from the vast majority of Rwandan Hutus who acted as either participants or bystanders to the violence. All but two of the interviewees connected their equal positioning of the Tutsi and their identification as a good human or Christian to their experiences with significant role models. In their own words, they informed us that their concepts of themselves and the Tutsis were developed from their moral education that they had received early in life from influential adults. For example, after being asked how she came to develop the good heart to which she attributed her rescuing, one interviewee stated:

What I can tell you is that I got this heart from my parents. I saw it from my parents. As I grew up, I saw that everyone, Hutu and Tutsi, were coming to my parents' house. Everyone was welcome. My parents had good hearts and I got it from them. ${ }^{68}$

Similarly, another rescuer explains:

It was the personality that I got from my parents. I am a Christian, a born again. I was saved. My parents taught me about being a good person and then when I became a pastor I was a pastor for everyone. I had to help them because I was a servant of God and it was the heart I inherited from my parents. ${ }^{69}$

For most of the rescuers interviewed, these significant role models were parents. There were also cases of auxiliary family members or community members taking on that role-uncles, grandparents, and in a few cases, neighbors or older friends. Regarding the rescue of Tutsis during the Rwandan genocide, a kind of grass roots network was created in the town of Mabare, leading to armed resistance against Hutu militia. ${ }^{70}$ These significant figures delivered an ethical education through their direct verbal teachings and their embodiment of ethical social practices. In the rescuers' personal narratives, their attempts to save Tutsis were driven in part by what they learned as children through ethical instruction, moralistic stories, and inspiring actions of role models.

The rescuers were explicitly taught to live at peace with all people, Hutu and Tutsi alike, and they witnessed their role models demonstrate generosity, service, advocacy, and tolerance. The moral education that rescuers received from role models took three forms: (1) direct verbal instruction concerning the proper treatment of others, (2) stories told by role models about past

${ }^{68}$ Participant \#1.

${ }^{69}$ Participant \#6.

${ }^{70}$ Frederico Varese and Meir Yaish, "Resolute Heroes: The Rescue of Jews During the Nazi Occupation of Europe," European Journal of Sociology 46 (2005), 153-168. 
deeds of compassion, typically including rescue efforts, and (3) the ethical deeds of these influential figures in their interactions with others, including Tutsis, that the rescuers themselves witnessed. Each of the three key elements of lessons, stories of past deeds, and demonstrated social practices has played an indelible role in the development of the rescuers' present sense of self. In the process of ascribing their own behavior to the influence of their role models, the rescuers emphasized how those elements directly contributed to their decisions to rescue.

First, most of them expressed gratitude to a father, mother, uncle, or grandparent for providing them the foundational moral clarity needed to respond to the genocidal violence of 1994. They cited the direct verbal instructions given by their role models about how to live well with others. When asked why he rescued, one rescuer invoked the lessons he learned from his parents: "We talked about it and were not valuing it. When I got home I would ask my parents about it, and they told me that people are the same, and that no one has different blood." ${ }^{\prime 71}$ This passage illustrates a pattern in which many rescuers invoked the same imagery used by their role models (in this case, the idea that humans share the same blood) when expressing their personal views as adults. This direct repetition of themes and metaphors was prominent throughout the rescuers' testimonies. Clearly, one of the key principles of the rescuers' moral education was to avoid ethnic division. Another rescuer also described his parents' influence:

My mother (who was a Hutu) told me never to get involved in the hatred of the Tutsi. Our parents told us about the past wars and violence. My father was always saying, "Please my children, never, never get involved in burning someone's home. I never want to hear that one of my children burned someone's home." So, if you teach this to children then they will not get involved in violence. ${ }^{72}$

This rescuer's parents were quite explicit about the importance of renouncing violence and ethnic divisions, and in the last sentence, we clearly see this rescuer making a causal link between one's parenting and personal involvement in violence.

For those rescuers who were inspired by their faith tradition, their moral education came from the Christian Bible. One rescuer recalled that her family was basically uneducated and illiterate, except for the fact that her mother was able to read the Bible. This rescuer received most of her moral lessons from her mother's repetition of biblical themes. Another rescuer recalled his father's relationship to the Bible:

My father modeled himself on the Holy Bible, and he taught us how to live using God's word. My father was a person who liked to pray all the time, and he would even gather our neighbors together in our home to pray. I remember that he liked to teach people around his community, sharing God's word through the Bible. Many people trusted him because of his commitment to God. We still try to live according to his example and the lessons he taught us. ${ }^{73}$

Second, the rescuers' moral education drew upon stories of their role models' responses to incidences of anti-Tutsi behavior in the years prior to the 1994 genocide. These stories focused on the suffering that Tutsis experienced in the past, such as having their homes burned and their property seized, facing systematic exclusion from education and employment opportunities, and being directly targeted for acts of violence. For many rescuers, the first salient memory of witnessing discrimination against the Tutsis or even hearing about distinctions between Hutus and Tutsis occurred during the first years of school. After seeing Hutu and Tutsi children being separated in school, they returned home confused and asked their parents about this. Their parents would respond by telling them that these ethnic distinctions did not matter and that they (the rescuers) should never participate in that kind of discrimination. In response to witnessing a violent raid

\footnotetext{
${ }^{71}$ Participant \#15.

${ }^{72}$ Participant \#3.

${ }^{73}$ Participant \#21.
} 
that initiated the fleeing of the Tutsis in his community in 1959, one rescuer recalls the impact of his father's words:

Our father was saying and pointing out how the people in the raid were not good. He believed it was the government that put these bad ideas in their heads, and he told us that there would be a time when we would be asked to join them. He told us not to be changed by these people, not to allow them to overturn us, and that we need to stand on our own position, as well as learn to be disciplined and maintain the culture of no division. ${ }^{74}$

The experience of seeing firsthand the injustices committed against people with whom the rescuer was quite familiar was reinforced by the prior lessons from his father, imploring him not to accept the government propaganda.

One interviewee told of how her husband - a rescuer-hid people in the earlier wars of 1959, 1962 and 1973. He would "tell [their] children about how people came to [their] house to kill the Tutsis, and he said to the people, 'Are these Tutsis not human like us? Were we not all created equally?'... He had no separations between people. He was very compassionate and people really appreciated him." ${ }^{\prime 75}$ Another rescuer's father exhibited generosity during a previous era of bloodshed by saving people who faced moral dangers from predators.

[My father] used to tell me stories as to how he helped people who were being hunted in 1959, 1960 and 1962. As conflicts were prevalent during those times, there was a family who was on a list of Tutsis to be targeted. When my dad saw this person's name on this list, he decided to go and tell his friend not to stay in his house anymore because he was on the list. ${ }^{76}$

Another rescuer found inspiration from his father's outspoken rebuke of killers during past conflicts. "When my father was still alive, he would always tell the killers that what they are doing is not good. 'It is not good to shed someone's blood,' he would say."77

The third component of the rescuers' moral education centered on witnessing the ethical behavior of their role models. Such behavior included acts of kindness by offering shelter to strangers, feeding the hungry, or caring for the sick. Most rescuers interviewed conveyed stories of inspiring rescue efforts by their role models: a mother offering shelter to the homeless, a father providing food to the hungry, an uncle giving clothes to the poor. ${ }^{78}$. The rescuers emulated these influential people for their compassion, inspiring them - the rescuers-to care for those in need around them - the homeless, hungry, impoverished, and destitute. The rescuers internalized such stories, which had a strong influence on their relations with others. When asked why he risked his life, one rescuer responded:

It was the heart I inherited from my parents. What I am, I learned from them. My parents loved their neighbors and were living well with them. They had no conflicts or problems with anyone. They would tell me to forgive mistakes, to never seek revenge, and to never create enemies. I tried to follow their steps by adapting their behaviors. The education I received from them, this is what helped me. I have no division in me and I never will. ${ }^{79}$

He made it very clear that his own behavior is the result of the way that his parents lived, illustrating a direct connection between this rescuer's sense of self and his parents' behavior. He internalized

\footnotetext{
${ }^{74}$ Participant \#22.

${ }^{75}$ Participant \#16.

${ }^{76}$ Participant \#9.

${ }^{77}$ Participant \#8.

${ }^{78}$ Participant \#1, \#2, \#4, \#6, \#9, \#10, \#14, \#15, \#16, \#19, and \#20.

${ }^{79}$ Participant \#16.
} 
their conscientious approach to social relationships and attributed his own acts of rescuing to this internalization.

The neighbor of one rescuer taught her how to care for others and to live as a family: "All people [in the neighborhood] were considered as family members, they are not just close friends." In another case the friends of the interviewee's parents were kind and loving, creating a culture of generosity and sharing with each other. These friends "would... give crops to those that didn't have crops. They would also advise us to give to others." ${ }^{80}$ Another rescuer praised a Tutsi woman for exhibiting a good heart in offering sanctuary for the homeless and providing resources to meet their tangible needs. This woman even showed kindness to aggressive individuals, which included her own husband. "All people loved her family," said one rescuer. ${ }^{81}$ Tragically, she was killed by a grown child that she had raised, who claimed that as a Tutsi, she was conspiring with other Tutsis to enslave Hutus.

One interviewee recalled how his parents taught him compassion for others in need. "The charity I got from my parents gave me the heart of growing up and loving others and wanting to take care of others who are in need." ${ }^{82}$ Another rescuer-a successful businessman-credits his father with showing him the immorality of his earlier, materialistic lifestyle. Because of this admonition from his father, the son later found true happiness in acts of selfless generosity, transcending regard for his own life.

One rescuer's mother demonstrated selfless love to others: "I followed the way that she loved people. I learned from her to have love and to love people because I would see how she would talk to people, even welcoming strangers and giving them shelter." 83 Another rescuer recalled how her mother taught her to promote peace with others and avoid division since "all Rwandans are the same, brothers and sisters... She would tell us to love each other, help each other." ${ }^{84}$ Another interviewee tried to emulate her grandmother, who "taught us to never to eat all of our food, but to always leave some for a visitor that may come. If a visitor comes when they are hungry, you want to have food for them. So we were always seeing her keeping extra sorghum flour and milk and porridge for potential visitors." ${ }^{85}$ In another case, the rescuer's grandfather "taught us how to live well with others... he was a person of peace and he wished that others would also be at peace." ${ }^{86}$ Another rescuer identified the impact her neighbor's example had on her:

[My neighbor] and I were very close, and I could share all my secrets with her. She lived a good life and she had a good heart. Her family was rich but they were not arrogant. My family was very poor, but we were still welcome in their home. She taught me many important lessons. Cecilia would advise me that no one could live without saving money or food. Whenever I would go into the market to buy things, and there was some balance left over, she would tell me to join my money with the people that needed help. She taught us to pool our extra money together so that there would be money available when one of us was going through a hard time.

I learned a lot from her. She was always advising me to be familiar with farming. Even though she was rich, [my neighbor] still loved to farm. This motivated me to love working as well. She was willing to do the work of the poor. When there were no seeds to cultivate, [she] would give us seeds. And she always taught us to give to others and to be human. [She] was a good lady with no separation and everyone could go to her house whether they were Hutu or Tutsi. Everybody in my community loved her family. ${ }^{87}$

\footnotetext{
${ }^{80}$ Participant \#3.

${ }^{81}$ Participant \#1.

82 Participant \#19.

${ }^{83}$ Participant \#6.

${ }^{84}$ Participant \#2.

${ }^{85}$ Participant \#4.

${ }^{86}$ Participant \#20.

${ }^{87}$ Participant \#1.
} 
This rescuer was inspired by her neighbor's virtues of generosity, tolerance and compassion, all of which exemplified her good heart. Another rescuer proclaimed his intention to adopt his mother's social practices as his own:

I saw that my mother loved people very much. I followed the way that she loved people. I learned from the ways that she would talk to and act with people. She would welcome strangers and give them shelter. She was not very religious, and she was not involved in political issues. She would always tell me to live well with people and to love others. If someone would come by our home and ask for something, she always gave to them and she expected that we helped them as well. She would tell us to always help people even when she wasn't around. She was advising us to be human. ${ }^{88}$

Not only did his mother exhibit helping behavior, she was also explicit about her expectation that her children follow her example. This is a clear expression of both the role model's deliberate efforts to instill her values on her children, and the rescuer's personal reflections about his mother's normative social practices. Through this rescuer's testimony, we see another repetition of two familiar themes. The first is the association between division and politics. Highlighting the fact that his mother was not involved in political issues reflects the belief held by several rescuers that politics were an instrument of division - and therefore to be mistrusted. The second is the idea of being human, of having a good heart. The social practices performed and encouraged by this role model were interpreted by the rescuer simply as the normative behaviors of a human: "she was advising us to be human." From this example, we see how role model ideology and behavior were internalized into the rescuers' personal meaning matrix.

One rescuer, whose grandmother agreed to look after several cows belonging to Tutsi neighbors who were forced to flee to Burundi, described the elaborate means by which the grandmother altered the cows' appearance in order to pass them off as her own.

When the Tutsi families were fleeing to Burundi, they would bring some of their things to my grandmother, and she would keep their stuff for them. It was hard for them to flee with cows, so my grandmother would keep the cows for her, but my grandparents could be targeted if anyone recognized the cows they were hiding. So my grandparents would get the dry banana leaves and they would burn the hair of the cows to make them a different color. After two weeks of doing this every day, a white cow would become brown, and then they could let that cow roam freely with the other cows without there being suspicion. They would also use a hot iron to change the direction of the cow's horns. They would keep the cow inside their one room house for a short period and then they would just mix them in with the rest of their cows. ${ }^{89}$

This story illustrates how the willingness to endure inconvenience, hardship and suffering for the sake of other community members was cast as an expected quality of a good person. Neither the role model nor the rescuer considered this kind of behavior extraordinary. Such endurance was seen simply as the logical application of ethical norms.

\section{Lessons Learned}

Most of the interviewees embraced the moralistic principle that each person attains full authenticity in right relations with others. Some rescuers invoked this principle by declaring that "my" life is connected to "yours," that "I" am enriched by close bonds with "you," and that "I" become fully realized in right relations with "you." One sees oneself-one's humanity-reflected in the character of others. This principle includes the exhortation to live as one, as a family, "as friends and brothers and sisters." One rescuer said, "A human being is a human being and a child is a child. You have to get together and never separate or segregate people."

\footnotetext{
${ }^{88}$ Participant \#6.
}

${ }^{89}$ Participant \#4. 
Many rescuers invoked the metaphor of a family to characterized Rwandans, often referring to everyone as brothers and sisters. Traditionally, families stick together, help each other, live together, and defend each other. Rescuers often used the phrase "living together" to refer to their way of being in general-whether in a literal sense, as in an actual home environment where all were welcome, or in a more theoretical sense, in that they avoided conflict, respected others, or lived in peace with their neighbors. Because they viewed the Tutsis as family members, the rescuers' sense of obligation toward them became personal and immediate. From the rescuers' point of view, when family members are threatened or in danger, one instinctively and unquestionably acts to protect them. One rescuer took in a Tutsi child and hid her among his own children. He recounted an episode during which a massacre was taking place in front of his house:

Many killers would come to my house to try and kill her. So when I heard them coming, I would lock the house with my family inside, and I'd stand outside. I would tell them, "If you are going to kill her, then go ahead and burn the entire house, throw a grenade and kill all of them! They are all my children! If you are going to kill her, then kill me too!"90

For this rescuer, his love for the human family prompted him to rescue. He proudly recalled how the girl whom he saved was still registered as his own child-he had taken her in as his own regardless of the fact that she was a complete stranger. For the rescuers who saved the lives of children, adopting them as their own was not uncommon.

Another rescuer considered the very idea of racial distinction a moral perversion. As he explained it,

The genuine "brotherhood of man" supersedes the fabricated notions of racial division. [The Interahamwe] kept saying, "If we found out you are hiding someone, you will die with him." But I had the conviction in my heart. No one chooses where he [comes] from. Others were also born like that in another group they didn't choose. So my purpose was whoever came to me I would welcome him. I think every human is like any other human, and I think when a human suffers I suffer too. I think God created every man in his own image. He never created races... My purpose in life was to live with everyone like a brother. ${ }^{91}$

Since God did not make ethnicities, the categories of Hutu and Tutsi are invalid, as illustrated in the following statements: "I didn't give things related to ethnicity much importance, I saw everyone as God's creation," "We are all God's children," and "God created us as one."92

Charles Kabwete Mulinda reports that some Tutsis credit their survival to the work of God rather than to their own efforts or even the efforts of the helpers. ${ }^{93}$ When analyzing the rescuer interviews, we see that their identities orbit around the character of the good human, the good Christian, or both. For the rescuers, being a good human or a good Christian is qualified through what it means to have a "good heart." With a good heart, one is driven - as if by an inner voiceto speak kindly of others, eschewing expressions of hatred based on race, nationality or tribal affiliation. A person with a good heart would intentionally share resources with neighbors, would live in peace with everyone, and would avoid divisive things, such as politics and ethnic distinctions. A person's good heart provides the wisdom to discern between the righteous path and the road to hell, to distinguish between good and evil. Guided by this wisdom, the rescuers found it impossible to tolerate the racist propaganda of Hutu extremists, finding these ideologies utterly abhorrent. In conversation with others, one speaks directly from the heart and is compelled to do

\footnotetext{
${ }^{90}$ Participant \#6.

${ }^{91}$ Participant \#2.

92 Participant \#2.

${ }_{93}^{93}$ Charles Kabwete Mulinda, "Crossing a border to Escape: Examples from the Gishamvu and Kigembe Communities of Rwanda," in Resisting Genocide: The Multiple Forms of Rescue, ed. Jacques Semelin, Claire Andrieu, and Sarah Gensburger (New York: Columbia University Press, 2011), 357.
} 
good deeds. A man who loses his heart is susceptible to evil, and so is inclined to say and do evil. "It is from the fullness of the heart that the mouth speaks." ${ }^{94}$

While a substantial number of rescuers ascribed their actions to their Christian faith, the notion of a good heart was also invoked by non-Christian rescuers. One non-Christian rescuer explained his actions to save Tutsis as simply being human. Notice the articulation of the qualities of generosity and universal love, and then the consummation of this self-description with the familiar reference to having a good heart:

I have love in me, and I'd like to see people living peacefully whether I know them or not. Another thing is that I always help people who need to be helped. For example, for the people who are sick or in prison, if I see that they need something, I feel that I should share with them what I have. This is why I saved that girl-I was just being human and having a good heart. ${ }^{95}$

But most interviewees who invoked the notion of a good heart as a basis for the rescue efforts understood this notion from a Christian perspective. Most of the rescuers interviewed repeatedly referenced this concept as a basis for their obligations to Tutsis. One Christian rescuer expressed how the possession of a good heart is the most important ingredient for producing moral behavior:

To me, I love people equally. I am this way because I am Christian. All people are the same and created the same by God. I rescued because of having a good heart. I never had a problem with people. I decide to live in peace with everyone. I don't refuse anyone who asks for my help. Those who are really serving God, they have love. There are some Christians who are hypocrites, maybe seeking food or better life conditions. We don't see things the same, we don't necessarily believe the same way, and we don't all have the same heart. ${ }^{96}$

Not only does this statement express the first two qualities of a person with a good heart, that is, generosity and unconditional love for all people, but it also demonstrates how the Christian identity alone was no guarantee of moral behavior and that having a good heart was the critical determinant of ethical conduct. The rescuers also believed that the killers themselves could be transformed if given proper instruction. The same kind of moral education could be used as a potential catalyst to reform the killers. The killers could be saved if introduced to a morally infused linguistic environment that the rescuers themselves acquired.

Before the genocide of 1994 , about $80 \%$ of Rwandans adopted Catholicism in combination with the traditional religious practices of Nyabingi. As Catholics, they would attend church in the morning and then worship in the afternoon, relying on the New Testament for guidance to live a virtuous life. ${ }^{97}$ According to the sacred text, one's good deeds come directly from the heart. "Good people produce good from the store of good within themselves: and evil people produce evil from the evil within them. For the words that the mouth utters come from the overflowing of the heart." 98

In the same way that the rescuers' secular positioning of "shared humanity" and the "one family" focused on oneness and equality, the Christian positioning also emphasized commonalities over differences. Often this religious positioning qualified oneness through shared bodily features, particularly with statements that highlighted that we all bleed the same blood. This emphasis echoes throughout a number of rescuer statements:

People are the same; no one has different blood. There is no difference between the Hutu and the Tutsi - we all have the same blood. No one has milk in his or her veins. Some people

\footnotetext{
${ }^{94}$ Matt. 12:34 Revised English Version.

${ }^{95}$ Participant \#6.

${ }^{96}$ Participant \#23.

${ }^{97}$ I thank Gedeon Patrick Hakiziman for providing this information during a personal conversation.

${ }^{98}$ Luke 6:45, Revised English Bible.
} 
betray others saying that they have tails, or that the Tutsis come from a different place, but I say God created one humanity, and all people bleed blood. No one bleeds milk. I have to love humans as I love myself.

Facilitated by their unequivocal faith in the righteousness of their positions, proper servants of God respond to genocide by rescuing. One rescuer recounted how one of his parents expressed doubt about God's mercy and justice. The parent said, "If the killers come here and kill someone, then I will know that the God I am serving is not the real God." While the rescuer's parents questioned God's moral authority, the rescuer himself never did. After the genocide, the rescuer became a pastor.

Most rescuers interviewed were motivated by a kind of fear that superseded any fear they had at the hands of fellow humans - that of God's wrath on Judgment Day. The fear of losing oneself, of losing one's good heart, became a source of energy for their rescuing efforts. Another rescuer found comfort in the promise of a better life in Heaven: "If you die while trying to save another's life, then you are on the right path of the life to come. That's what motivated me. Whether I died or not, God would be happy with what I was doing."

Some rescuers expressed their gratitude to God for answering their prayers, proclaiming that he intervened directly to save Tutsis. For example, God is credited with "pushing the killers away" from the house where Tutsis were hiding, or causing rescuers to leave an area where Tutsis were vulnerable to fatal attacks. One rescuer reports, "I saw one attack coming from behind my house. I prayed to God, 'Look - they have attacked me. I need you to do some miracle."'99 She credits her survival to God, who somehow enticed the attackers to suddenly depart from the area where the Tutsis were hiding. The prayers of some rescuers were answered in what they described as a miracle from God. Other rescuers cited specific directives from God about the most effective tactics for confronting the Interahamwe.

The rescuers claimed that, because of their good heart, they could not turn away those seeking safety in the face of mortal danger, risking the same fate as those they sought to save. This expectation established an existential bond between them and the Tutsis they harbored in their homes, a bond sealed by the knowledge that the rescuers would live or die alongside those seeking sanctuary. For some rescuers this bond was actually a source of comfort; as one rescuer explained, "Even if I die, I'll die happy because I have seen people who I secured that are still alive." 100 And to the rescuers, this bond reflected their good heart and their covenant with God. On this view, the eyes of one's good heart are opened to the suffering and needs of others.

Most rescuers acknowledged the intense fear they experienced at the outset of the extermination campaign. The anti-Tutsi propaganda was an existential threat to peace-loving Hutus.

What happened to others can happen to us as well, and we were not happy with what was happening to them... We couldn't sleep. We stayed up with fear filling us, thinking that the [Interahamwe] are coming and they will kill us. But we could see that there was nothing to do since God is the one who knows if we are meant to die. ${ }^{101}$

But the rescuers were not paralyzed by their fears. Some rescuers recounted how their faith only strengthened their resolve to take the right path no matter the consequences. One rescuer claimed that his faith gave him the strength to endure frequent beatings and threats to his life-and even on one occasion being ordered to dig his own grave. Yet even as he and the other rescuers described their experiences and actions, they refused to characterize themselves as heroes, preferring instead to depict their rescuing efforts as ordinary-even obligatory - for anyone with a sense of moral integrity.

\footnotetext{
${ }^{99}$ Participant \#5.

${ }^{100}$ Participant \#2.

101 Participant \#32.
} 


\section{Conclusion}

The rescuers interviewed for this research resisted the propaganda disseminated by Hutu extremists that Tutsis are a separate race, committed to conquering Rwanda and enslaving all Hutus. Instead, these rescuers held fast to their humanitarian values, recognizing everyone's inherent moral worth and potential vulnerability to suffering. A majority of the interviewees found inspiration in their Christian faith, which they claim gave them strength during the darkest days of the slaughter. These interviewees repeatedly invoked their bond with God, driven by their good heart to follow his law. For all the rescuers interviewed, the moral education they received from role models took the form of direct verbal instruction on the proper treatment of others, stories the role models recounted about past deeds, and accounts of general ethical practices. The rescuers' moral education took place within a localized narrative environment that operated simultaneously within the context of the larger, societal narrative, and contributed to their sense of moral bond with Tutsis-one they could not in good conscience ignore. Undergirded by their sense of a common humanity and motivated by their Christian faith, the rescuers clung to their conviction all Rwandans were part of the same "family," and they heralded the amalgam of these two positions, rooted in a Christian perspective: that all people are created equally in God's image and that we are all God's children. These alternative positions intertwined the rescuers' self-image with compassion for those in need, spurring them to act with courage on behalf of the Tutsis.

\section{Bibliography}

Beer, Suzanne. "Aid Offered Jews in Nazi Germany: Research Approaches, Methods, and Problems." Online Encyclopedia of Mass Violence (2014). Accessed February 19, 2016, http:// www.massviolence.org/Aid-Offered-Jews-in-Nazi-Germany.

Bierhoff, Hans. W., Renate Klein, and Peter Kamp. "Evidence for the Altruistic Personality from Data on Accident Research." Journal of Personality 59 (1991): 263-280. http://dx.doi. org/10.1111/j.1467-6494.1991.tb00776.x

Blustein, Jeffrey. The Moral Demands of Memory. New York: Cambridge University Press, 2008. http://dx.doi.org/10.1017/CBO9780511818615

Chrétien, Jean-Paul and Reporters sans Frontières. Rwanda: Les médias du génocide. Paris: Éditions Karthala, 1995.

Croes, Marnix. "The Holocaust in the Netherlands and the Rate of Jewish Survival." Holocaust and Genocide Studies 20, no. 3 (2006): 474-499. http://dx.doi.org/10.1093/hgs/dcl022

Des Forges, Alison. Leave None to Tell the Story. New York: Human Rights Watch, 1991.

Düring, Marten. "The Dynamics of Helping Behaviour for Jewish Refugees During the Second World War. The Importance of Brokerage." In Knoten und Kanten: soziale Netzwerkanalyse in Geschichts- und Politikwissenschaften, edited by Markus Gamper, Linda Reschke and Marten Düring, 321-338. Bielefeld: Transcript, 2015. http://dx.doi.org/10.14361/9783839427422-010

Elster, Jon. "Rational Choice History: A Case of Excessive Ambition." American Political Science Review 94, no. 3 (2005): 685-695. http://dx.doi.org/10.1017/S0003055400271360

Fogelman, Eva. Conscience and Courage: Rescuers of Jews During the Holocaust. New York: Doubleday, 1994.

Fujii, Lee Ann. "Rescuers and Killer-Rescuers during the Rwanda Genocide: Rethinking Standard Categories of Analysis." In Resisting Genocide: the Multiple Forms of Rescue, edited by Jacque Semelin, Claire Andrieu, and Sarah Gensburger, 145-157. New York: Columbia University Press, 2011.

Galston, William A. "Cosmopolitan Altruism." Social Philosophy and Social Policy 10 (1993): 118-134.

Gudehus, Christian. "Helping the Persecuted. Heuristics and Perspectives (exemplified by the Holocaust)." Online Encyclopedia of Mass Violence (2016). Accessed August 17, 2016, http:// www.sciencespo.fr/mass-violence-war-massacre-resistance/en/document/helpingpersecuted-heuristics-and-perspectives-exemplified-holocaust.

Hatzfeld, Jean. Machete Season: The Killers in Rwanda Speak. New York: Farrar, Straus and Giroux, 2013. 
King, Elisabeth. "Memory Controversies in Post-Genocide Rwanda:Implications for Peacebuilding." Genocide Studies and Prevention 5, no. 3 (December 2010): 293-309. http://dx.doi.org/10.3138/ gsp.5.3.293

Krebs, Dennis L. and Frank Van Hesteren. "The Development of Altruistic Personality." In Embracing the Other: Philosophical, Psychological, and Historical Perspectives on Altruism, edited by Pearl M. Oliner, Samuel P. Oliner, Lawrence Baron, Lawrence A. Blum, Dennis Krebs, and M. Zuzanna Smoleneska, 1142-169. New York: New York University Press, 1992.

Moore, Bob. Survivors: Jewish Self-Help and Rescue in Nazi-Occupied Western Europe. Oxford and New York City: Oxford University Press, 2010.

Mulinda, Charles Kabwete "Crossing a border to Escape: Examples from the Gishamvu and Kigembe Communities of Rwanda." In Resisting Genocide: The Multiple Forms of Rescue, edited by Jacques Semelin, Claire Andrieu, and Sarah Gensburger, 345-361. New York: Columbia University Press, 2011.

Oliner, Pearl. M. and Samuel P. Oliner. The Altruistic Personality: Rescuers of Jews in Nazi Europe. New York: Free Press, 1988.

"Promoting Extensive Altruistic Bonds: A Conceptual Elaboration and Some Pragmatic Implications." In Embracing the Other: Philosophical, Psychological, and Historical Perspectives on Altruism, edited by Pearl M. Oliner, Samuel P. Oliner, Lawrence Baron, Lawrence A. Blum, Dennis Krebs, and M.Zuzanna Smoleneska, 369-389. New York: New York University Press, 1992.

Rothbart, Daniel and Tom Bartlett. "Rwandan Radio and Hutu/Tutsi Positioning." In Global Conflict Resolution through Positioning Theory, edited by Fathali M. Moghaddam, Rom Harré, and Niomi Lee, 227-246. New York: Springer, 2008. http://dx.doi.org/10.1007/978-0-387-72112$\underline{513}$

Rothbart, Daniel and Karina Korostelina. "Moral Denigration of the Other." In Identity, Morality, and Threat: Studies in Violent Conflict, edited by Daniel Rothbart and Karina Korostelina, 2958. Lanham: Lexington Books, 2006.

Staub, Ervin. Positive Social Behavior and Morality. Vol. 2. New York: Academic Press, 1979.

Suedfeld, Peter and Stefanie de Best. "Value Hierarchies of Holocaust Rescuers and Resistance Fighters." Genocide Studies and Prevention 3, no. 1 (2008): 31-42. http://dx.doi.org/10.3138/ gsp.3.1.31

Straus, Scott. "How many Perpetrators were there in the Rwandan Genocide?" Journal of Genocide Research 6, no. 1 (2004): 85-98. http://dx.doi.org/10.1080/1462352042000194728

Semujanga, Josias. Origins of Rwandan Genocide. Amherst: Humanity Books, 2003.

Tec, Nechama. When Light Pierced the Darkness: Christian Rescue of the Jews in Nazi-occupied Poland. New York: Oxford University Press, 1986.

. "Who Dared to Rescue Jews, and Why?" In Resisting Genocide: The Multiple Forms of Rescue, edited by Jacques Semelin, Clair Andrieu, and Sarah Gensburger, 101-112. New York: Columbia University Press, 2011.

Van Hesteren, Erika. "The Self in Moral Agency: Toward a Theoretical Model of the Ideal Altruistic Personality." In Embracing the Other: Philosophical, Psychological, and Historical Perspectives on Altruism, edited by Pearl M. Oliner, Samuel P. Oliner, Lawrence Baron, Lawrence A. Blum, Dennis Krebs, and M. Zuzanna Smoleneska, 170-193. New York: New York University Press, 1992.

Varese, Frederico, and Meir Yaish. "Resolute Heroes: The Rescue of Jews During the Nazi Occupation of Europe." European Journal of Sociology 46 (2005): 153-168. http://dx.doi. org/10.1017/S0003975605000068 


\section{Appendix \\ Interview Questions}

Pre-Genocide

- Childhood

- Where and when were you born?

- What was the economic status of your family?

- What was the religious status of your family?

- What was you family's relationship to the community and neighbors?

- Did you attend school? If so, how much schooling did you attend?

- Adulthood

- Did you marry? When?

- Did you have children? How many?

- What did you do for work?

- What was your religious status?

- What was your financial status?

- What was your relationship with the community like?

- Did you have Tutsi friends or relatives?

- Where you involved in politics?

- Right before the genocide

- Where you aware of what was going on?

- Did you listen to the radio? If so, what was your impression of what was being broadcasted?

- Did anyone try to recruit you into joining the killings?

During the Genocide

- Where were you when you first heard that the genocide started?

- What was your experience during the genocide?

- When did you start to help people?

- Where they friends, strangers, neighbors, etc?

- How many people did you help?

- How did you help them?

- Was anyone harmed? Property damaged?

- What were your interactions with the people participating in the killings?

- Why did you do this?

- What is your understanding of your actions?

\section{Post Genocide}

- Has your life changed since the genocide? If yes, how so?

- How have others responded to your actions? Have you received any praise or hardship because of rescuing?

- Are you still in contact with any of the survivors you helped? 